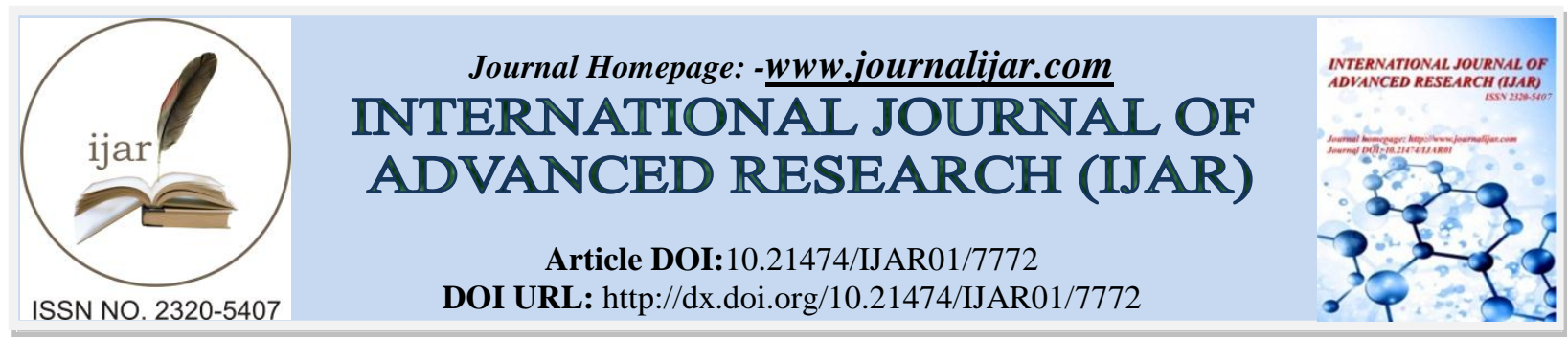

RESEARCH ARTICLE

\title{
URBAN ENVIRONMENTAL CONSERVATION MEASURES IN KODAIKANAL REGION TAMIL NADU.
}

Dr. I. Sundar.

Associate Professor of Economics, Directorate of Distance Education, Annamalai University.

\section{Manuscript Info}

Manuscript History

Received: 25 July 2018

Final Accepted: 31 August 2018

Published: September 2018

\section{Abstract}

It is clear that the world is becoming more and more urban. It has been predicted that by the year $2050,70 \%$ of the human population on Earth will live in cities $^{1}$. There are many environmental problems that are associated with so much urbanization on the landscape. This paper deals with urban environmental conservation measures in Kodaikanal region in Tamil Nadu. It outlines the various indicators of urban environmental conservation measures and such qualitative indicators are quantified with the help of 5 point rating scale. This paper concludes with some interesting findings along policy suggestions.

Copy Right, IJAR, 2018,. All rights reserved.

\section{Introduction:-}

Environmental protection is practiced for protecting the natural environment on individual, organization controlled by governmental levels, for the benefit of both the environment and humans. Due to the pressures of overconsumption, population and technology, the biophysical environment is being degraded, sometimes permanently. This has been recognized, and governments have begun placing restraints on activities that cause environmental degradation. Since the 1960s, activity of environmental movements has created awareness of the various environmental problems. There is no agreement on the extent of the environmental impact of human activity and even scientific dishonesty occurs, so protection measures are occasionally debated.

The environmental impacts of modern cities go beyond their surrounding regions. Size, rate, and connections of the modern metropolis show a global impact. The ecological footprint is one measure of these effects. Urban environmental problems are mostly inadequate water supply, wastewater, solid waste, energy, loss of green and natural spaces, urban sprawl, pollution of soil, air, traffic, noise, etc. All these problems are particularly serious in developing countries and countries with economic transition, where there is a conflict between the short-term economic plan and the protection of the environment.

Air and water pollution and waste are the main environmental problems in most cities. The underlying causes of air pollution of the city are the processes that are associated with the burning of fossil fuels (production and consumption of energy for heating buildings, industrial activities, traffic). Noise is also a special form of pollution, which burdens the urban population. Urbanization causes numerous effects on water resources; these effects can change the hydrology, water quality and availability of aquatic habitats. Deterioration in the quality of ground and river water in the cities is mainly due to the water consumption of the population and industry. Contamination is usually caused by industrial activity as well as the disposal of waste, so in cities is dominated water pollution from municipal and industrial wastewater. The city is marked by large inputs of energy, water, food and a variety of raw materials, resulting in large quantities of goods, as well as waste, which means a huge loss of natural resources in the 
form of raw materials and energy. Urban ecosystems are indicated by a very high energy consumption and large amounts of solid waste that accumulate in certain places. In this way, they represent landscape degradation factor and adversely affect the quality of water resources and urban air.

\section{Review on the subject}

Patricia Romero-Lankao, et.al. (2013) explored the health risks related to air pollution and temperature extremes within three Latin American cities: Bogota, Colombia, Mexico City, Mexico, and Santiago, Chile. Duo Qin (2010) examined the long-run relationship between industrial pollution and income in China using provincial panel data. Katja Coneus and Christa Katharina Spie (2010) examined the impact of outdoor and indoor pollution on children's health from birth until the age of three years in Germany. Sunil Chandrasiri (2006) estimated the health costs of particulate emissions from diesel-powered vehicles in Colombo City, Sri Lanka. Budy P. Resosudarmo and Lucentezza Napitupulu (2004) estimated the health cost of Jakarta's air pollution. It is found that in 1999 reached \$US220 million. In 2001 the government planned to launch a program to control vehicle emissions.Hercules Haralambides and Girish Gujar (2012) applied data model to evaluate dry port efficiency, while taking into account the $\mathrm{CO}_{2}$ emissions caused by the transport of containers from dry ports, located in the North Capital Region of India. Amit Garg (2011) reported about the human health impacts from urban air pollution in India. M.N. Murty (2010) examined the possibility of using economic instruments, especially pollution taxes and bargaining approaches, as a means to encourage people's participation in environmental management in India. Ramakrishna B. M and Jayasheela (2010) reported that in India, rapid growth of population, poverty, urbanization, industrialization and several related factors are responsible for the rapid degradation of the environment. Kakali Mukhopadhyay (2008) estimated the emissions related to fossil fuel combustion in India and also identified the factors responsible for changes in those emissions during the 1980s and 1990s. Prakash Nelliyat (2007) discussed the textile industrial growth in Tiruppur in the context of global diversification of textile manufacturing and trade with emphasis on employment, income and foreign exchange in regional economy perspective such situation leads to side effects in the form of environmental pollution. M. Narsimha Murty, et.al. (2007) found that there is a significant variation in marginal cost of pollution abatement or shadow prices of bad outputs across the firms and an increasing marginal cost of pollution abatement with respect to pollution reduction by the firms. Sacchidananda Mukherjee and Prakash Nelliyat (2006) examined the environmental and socio-economic impacts of industrial effluents on irrigation water in different industrial locations at Mettupalayam taluk through primary surveys and secondary information. Ramprasad Sengupta and Subrata Mandal (2005) estimated the health damage cost of urban air pollution for 35 major urban agglomerations of India arising from automotive emissions and the savings that can be achieved by the regulation of fuel quality so as to conform to the Euro norms.

\section{Methods and Materials:-}

This paper deals with urban residents rating on urban environmental conservation measures in Kodaikanal city. The researcher has selected the 300 households representing various occupation groups in different parts of the city under stratified random sampling method. The relevant data on urban environmental conservation measures are collected from the respondents with the help of interview schedule method. The collected data are classified and tabulated with the help of computer programming. Cross tabulation has been done by putting independent variables and dependent variables. The collected qualitative data are converted into quantitative data with the help of 5 point rating scale. The data analysis has been carried out with the help of mean, ANOVA two way test and t test.

\section{Results and Discussion:-}

This section deals with respondents' rating on environmental conservation measures. It can be assessed with the help of 36 factors on a 5 point rating scale. These include utilization of alternative energy sources, identification of alternative energy sources for public transport, need of programmes to deal specifically with pollution, developing large number of clean up programmes, introducing green boxes in recycling, utilization of large number of environmentally friendly vehicles, sustainable long range environmental planning, proper placement of garbage binds, appointment of more sweepers to clean the streets, provision of more volunteer opportunities for young people in environmental conservation, need more information regarding environmental policies and incentives, need to improve the quality of air, measures to improve air quality management, improving waste management, planting more number of trees and creation of green spaces, preserving ecosystem and farmland, measures to make schools participate in recycling programmes, effective enforcement of environmental regulations, accepting more plastics in recycling, starting new clean air initiatives, frequently conducting antilittering campaign, measures to make community involvement in clean up programmes, need more publicity on hazardous waste profile, improving public 
transport, improving sewage system, distribution of large number of recycling bins, effective approach to recycling of waste, increasing energy efficiency, public information on location of waste dump sites, creation of environmental awareness through mass media, effective implementation of antilittering laws, public debate focusing on preventing environmental issues, provide funding for research and use of wind, solar, biomass and other renewable energies, Need more promotion and education of public in sanitation, establishing volunteer clean up programmes and levying heavier fines on littering.

Table 1:-Age Wise Respondents' Rating on Environmental Conservation Measures

\begin{tabular}{|c|c|c|c|c|c|c|c|}
\hline Variables & No & nn & mo & $m n$ & $\forall 0$ & $\nabla n$ & Mean \\
\hline Improving sewage system & 2.98 & 2.79 & 2.65 & 2.49 & 2.35 & 2.16 & 2.57 \\
\hline $\begin{array}{l}\text { Effective enforcement of environmental } \\
\text { regulations }\end{array}$ & 3.43 & 3.24 & 3.10 & 2.94 & 2.80 & 2.61 & 3.02 \\
\hline $\begin{array}{l}\text { Planting more number of trees and creation of } \\
\text { green spaces }\end{array}$ & 3.62 & 3.43 & 3.29 & 3.13 & 2.99 & 2.80 & 3.21 \\
\hline Sustainable long range environmental planning & 4.19 & 4.00 & 3.86 & 3.70 & 3.56 & 3.37 & 3.78 \\
\hline Preserving ecosystem and farmland & 3.56 & 3.37 & 3.23 & 3.07 & 2.93 & 2.74 & 3.15 \\
\hline Utilization of alternative energy sources & 4.28 & 4.25 & 4.22 & 4.20 & 4.18 & 4.17 & 4.20 \\
\hline Improving public transport & 3.04 & 2.85 & 2.71 & 2.55 & 2.41 & 2.22 & 2.63 \\
\hline Increasing energy efficiency & 2.80 & 2.61 & 2.47 & 2.31 & 2.17 & 1.98 & 2.39 \\
\hline $\begin{array}{l}\text { Utilization of large number of environmentally } \\
\text { friendly vehicles }\end{array}$ & 4.20 & 4.11 & 3.97 & 3.81 & 3.67 & 3.58 & 3.89 \\
\hline Accepting more plastics in recycling & 3.36 & 3.17 & 3.03 & 2.87 & 2.73 & 2.54 & 2.95 \\
\hline Proper placement of garbage binds & 4.14 & 3.95 & 3.81 & 3.65 & 3.51 & 3.32 & 3.73 \\
\hline Levying heavier fines on littering & 2.11 & 2.02 & 1.88 & 1.72 & 1.58 & 1.49 & 1.80 \\
\hline Need more publicity on hazardous waste profile & 3.11 & 2.92 & 2.78 & 2.62 & 2.48 & 2.29 & 2.70 \\
\hline Introducing green boxes in recycling & 4.26 & 4.17 & 4.03 & 3.97 & 3.73 & 3.54 & 3.95 \\
\hline Effective approach to recycling of waste & 2.86 & 2.67 & 2.53 & 2.37 & 2.23 & 2.04 & 2.45 \\
\hline Improving waste management & 3.75 & 3.56 & 3.42 & 3.26 & 3.12 & 2.93 & 3.34 \\
\hline $\begin{array}{l}\text { Public information on location of waste dump } \\
\text { sites }\end{array}$ & 2.75 & 2.56 & 2.42 & 2.26 & 2.12 & 1.93 & 2.34 \\
\hline Distribution of large number of recycling bins & 2.92 & 2.73 & 2.59 & 2.43 & 2.29 & 2.10 & 2.51 \\
\hline $\begin{array}{l}\text { Measures to make schools participate in } \\
\text { recycling programmes }\end{array}$ & 3.49 & 3.30 & 3.16 & 3.00 & 2.86 & 2.67 & 3.08 \\
\hline $\begin{array}{l}\text { Developing large number of clean up } \\
\text { programmes }\end{array}$ & 4.20 & 4.11 & 4.07 & 3.91 & 3.87 & 3.78 & 3.99 \\
\hline Establishing volunteer clean up programmes & 2.18 & 2.09 & 1.95 & 1.79 & 1.65 & 1.56 & 1.87 \\
\hline
\end{tabular}

Table 1:-Age Wise Respondents' Rating on Environmental Conservation Measures (Cont..)

\begin{tabular}{|l|c|c|c|c|c|c|c|}
\hline $\begin{array}{l}\text { Measures to make community involvement in } \\
\text { clean up programmes }\end{array}$ & 3.17 & 2.98 & 2.84 & 2.68 & 2.54 & 2.35 & 2.76 \\
\hline Need to improve the quality of air & 3.88 & 3.69 & 3.55 & 3.39 & 3.25 & 3.06 & 3.47 \\
\hline Measures to improve air quality management & 3.79 & 3.60 & 3.46 & 3.30 & 3.16 & 2.97 & 3.38 \\
\hline Starting new clean air initiatives & 3.30 & 3.11 & 2.97 & 2.81 & 2.67 & 2.48 & 2.89 \\
\hline $\begin{array}{l}\text { Need programmes to deal specifically with } \\
\text { pollution }\end{array}$ & 4.25 & 4.21 & 4.17 & 4.10 & 4.07 & 3.74 & 4.09 \\
\hline $\begin{array}{l}\text { Need more promotion and education of public } \\
\text { in sanitation }\end{array}$ & 2.25 & 2.16 & 2.02 & 1.86 & 1.72 & 1.63 & 1.94 \\
\hline $\begin{array}{l}\text { Creation of environmental awareness through } \\
\text { mass media }\end{array}$ & 2.69 & 2.50 & 2.36 & 2.20 & 2.06 & 1.87 & 2.28 \\
\hline $\begin{array}{l}\text { Need more information regarding } \\
\text { environmental policies and incentives }\end{array}$ & 3.94 & 3.75 & 3.61 & 3.45 & 3.31 & 3.12 & 3.53 \\
\hline $\begin{array}{l}\text { Identification of alternative energy sources for } \\
\text { public transport }\end{array}$ & 4.25 & 4.22 & 4.20 & 4.16 & 4.12 & 3.89 & 4.14 \\
\hline Provide funding for research and use of wind, & 2.48 & 2.29 & 2.15 & 1.99 & 1.85 & 1.66 & 2.07 \\
\hline
\end{tabular}




\begin{tabular}{|l|c|c|c|c|c|c|c|}
\hline solar, biomass and other renewable energies & & & & & & & \\
\hline $\begin{array}{l}\text { Provision of more volunteer opportunities for } \\
\text { young people in environmental conservation }\end{array}$ & 3.99 & 3.80 & 3.66 & 3.50 & 3.36 & 3.17 & 3.58 \\
\hline $\begin{array}{l}\text { Public debate focusing on preventing } \\
\text { environmental issues }\end{array}$ & 2.57 & 2.38 & 2.24 & 2.08 & 1.94 & 1.75 & 2.16 \\
\hline Frequent conducting antilittering campaign & 3.23 & 3.04 & 2.90 & 2.74 & 2.60 & 2.41 & 2.82 \\
\hline Appoint of more sweepers to clean the streets & 4.05 & 3.86 & 3.72 & 3.56 & 3.42 & 3.23 & 3.64 \\
\hline Effective implementation of antilittering laws & 2.63 & 2.44 & 2.30 & 2.14 & 2.00 & 1.81 & 2.22 \\
\hline Average & 3.38 & 3.22 & 3.09 & 2.94 & 2.81 & 2.64 & 3.01 \\
\hline
\end{tabular}

Source: Computed from primary data

\begin{tabular}{|c|c|c|c|c|c|}
\hline \multicolumn{6}{|c|}{ ANOVA } \\
\hline Source of Variation & $S S$ & $d f$ & $M S$ & $F$ & F crit \\
\hline Variation due to environmental conservation measures & 106.5701 & 35 & 3.044859 & 754.512 & 1.490573 \\
\hline Variation due to age structure & 13.29891 & 5 & 2.659783 & 659.0906 & 2.265761 \\
\hline Error & 0.706219 & 175 & 0.004036 & & \\
\hline Total & 120.5752 & 215 & & & \\
\hline
\end{tabular}

Data presented in table 1 indicate the age wise respondents' rating on environmental conservation measures. It could be noted that out of the 36 environmental conservation measures, the respondents rate the utilization of alternative energy sources is the first level measure on environmental conservation and it is evident from their secured a mean score of 4.20 on a 5 point rating scale. Identification of alternative energy sources for public transport is rated at second level environmental conservation measure and it is estimated from the respondents' secured a mean score of 4.14 on a 5 point rating scale. The respondents rate the need programmes to deal specifically with pollution is the third level environmental conservation measure. It is evident from their secured a mean score of 4.09 on a 5 point rating scale. The respondents rank the fourth level indicator of environmental conservation by citing the fact that developing large number of clean up programmes and it is observed from the respondents' secured a mean score of 3.99 on a 5 point rating scale. Introducing green boxes in recycling is rated at fifth level environmental conservation measure and it could be known from the respondents' secured a mean score of 3.95 on a 5 point rating scale.

The respondents' rate the utilization of large number of environmentally friendly vehicles is the sixth level measure on environmental conservation and it is revealed from their secured a mean score of 3.89 on a 5 point rating scale. Need for sustainable long range environmental planning is rated at seventh level measure on environmental conservation and it is observed from the respondents' secured a mean score of 3.78 on a 5 point rating scale. The respondents' rate the proper placement of garbage binds and it is their eighth level ranking. It is evident from their secured a mean score of 3.73 on a 5 point rating scale. The respondents rank the ninth level measure on environmental conservation by citing the need that appointment of more number of sweepers to clean the streets as per their secured a mean score of 3.64 on a 5 point rating scale. Provision of more volunteer opportunities for young people in environmental conservation is rated at tenth level measure on environmental conservation and it is evident from the respondents' secured a mean score of 3.58 on a 5 point rating scale. The respondents rate the need for more information regarding environmental policies and incentives is the eleventh level indicator of environmental conservation and it could be known from their secured a mean score of 3.53 on a 5 point rating scale. Need to improve the quality of air is rated at twelfth level measure on environmental conservation and it is reflected from the respondents' secured a mean score of 3.47 on a 5 point rating scale. The respondents rank the thirteenth level measure on environmental conservation by citing the need to improve air quality management. It is evident from their secured a mean score of 3.38 on a 5 point rating scale. The respondents rank the fourteenth level measure on environmental conservation by citing the fact that improving waste management and it is clear from their secured a mean score of 3.34 on a 5 point rating scale. Planting more number of trees and creation of green spaces is rated at fifteenth level measure on environmental conservation as per the respondents' secured a mean score of 3.21 on a 5 point rating scale. The respondents' rate the preserving ecosystem and farmland and it is their sixteenth level ranking. It is evident from their secured a mean score of 3.15 on a 5 point rating scale. The respondents rank the seventeenth level indicator of environmental conservation by citing the fact that measures to make schools participate in recycling programmes as per their secured a mean score of 3.08 on a 5 point rating scale. Effective enforcement of environmental regulations is rated at eighteenth level measure on environmental conservation and it is evident from the respondents' secured a mean score of 3.02 on a 5 point rating scale. The respondents' rate the 
accepting more plastics in recycling is the nineteenth level measure on environmental conservation and it could be known from their secured a mean score of 2.95 on a 5 point rating scale. Starting new clean air initiatives is rated at twentieth level measure on environmental conservation and it is reflected from the respondents' secured a mean score of 2.89 on a 5 point rating scale. The respondents rank the twenty first level measure on environmental conservation by citing the need for frequently conducting antilittering campaign. It is evident from their secured a mean score of 2.82 on a 5 point rating scale. Measures to make community involvement in clean up programmes is rated at twenty second level measure on environmental conservation as per the respondents' secured a mean score of 2.76 on a 5 point rating scale. The respondents' rate the need of more publicity on hazardous waste profile and it is their twenty third level ranking. It is evident from their secured a mean score of 2.70 on a 5 point rating scale. The respondents rank the twenty fourth level measure on environmental conservation by citing the need for improving public transport system as per their secured a mean score of 2.63 on a 5 point rating scale. Improving sewage system is rated at twenty fifth level measure on environmental conservation and it is evident from the respondents' secured a mean score of 2.57 on a 5 point rating scale. The respondents rate the distribution of large number of recycling bins is the twenty sixth level measure on environmental conservation and it could be known from their secured a mean score of 2.51 on a 5 point rating scale. Effective approach to recycling of waste is rated at twenty seventh level measure on environmental conservation and it is reflected from the respondents' secured a mean score of 2.45 on a 5 point rating scale. The respondents rank the twenty eighth level measure on environmental conservation by citing the fact that increasing energy efficiency. It is evident from their secured a mean score of 2.39 on a 5 point rating scale. Public information on location of waste dump sites is rated at twenty ninth level measure on environmental conservation and it is observed from the respondents' secured a mean score of 2.34 on a 5 point rating scale. The respondents' rate the creation of environmental awareness through mass media is their thirtieth level ranking. It is evident from their secured a mean score of 2.28 on a 5 point rating scale. The respondents rank the thirty first level measure on environmental conservation by citing the fact that effective implementation of antilittering laws as per their secured a mean score of 2.22 on a 5 point rating scale. Public debate focusing on preventing environmental issues is rated at thirty second level indicator of environmental conservation and it is evident from the respondents' secured a mean score of 2.16 on a 5 point rating scale. The respondents rate the provide funding for research and use of wind, solar, biomass and other renewable energies is the thirty third level indicator of environmental conservation and it could be known from their secured a mean score of 2.07 on a 5 point rating scale. Need of more promotion and education of public in sanitation is rated at thirty fourth level measure on environmental conservation and it is reflected from the respondents' secured a mean score of 1.94 on a 5 point rating scale. The respondents rank the thirty fifth level measure on environmental conservation by citing the fact that establishing volunteer clean up programmes. It is evident from their secured a mean score of 1.87 on a 5 point rating scale. The respondents rank the thirty sixth level measure on environmental conservation by citing the fact that levying heavier fines on littering and it is clear from their secured a mean score of 1.80 on a 5 point rating scale.

The respondents belong to the 20-25 years age group rank the first position in their overall rated measures on environmental conservation as per their secured a mean score of 3.38 on a 5 point rating scale. The respondents come under the age group in the range of 25-30 years register the second position in their overall rated measures on environmental conservation as per their secured a mean score of 3.22 on a 5 point rating scale. The respondents included in the age group in the range of 30-35 years hold the third position in their overall rated measure on environmental conservation as per their secured a mean score of 3.09 on a 5 point rating scale. The respondents belong to the 35-40 age group register the fourth position in their overall rated measures on environmental conservation as per their secured a mean score of 2.94 on a 5 point rating scale. The respondents come under the age group in the range of 35-40 years register the fifth position in their overall rated measures on environmental conservation as per their secured a mean score of 2.81 on a 5 point rating scale. The respondents observed in the range of 45-50 years age group turn down to last position in their overall rated measures on environmental conservation as per their secured a mean score of 2.64 on a 5 point rating scale.

The anova two way model is applied for further discussion. The computed anova value 754.51 is greater than its tabulated value at 5 percent level significance. Hence, the variation among the measures on environmental conservation is statistically identified as significant. In another point, the computed anova value 659.09 is greater than its tabulated value at 5 percent level significance. Hence, the variation among the age groups is statistically identified as significant as per the respondents rated measures on environmental conservation. 
Table 2:-Education Wise Respondents' Rating on Environmental Conservation Measures

\begin{tabular}{|c|c|c|c|c|c|c|}
\hline+2 & $a-1 \cdot-$ & 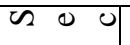 & $I \cdot-$ on & $\nabla=\nabla$ & A 10 in & Mean \\
\hline Improving sewage system & 1.80 & 2.41 & 2.68 & 2.95 & 3.11 & 2.57 \\
\hline Effective enforcement of environmental regulations & 2.25 & 2.86 & 3.13 & 3.40 & 3.56 & 3.02 \\
\hline $\begin{array}{l}\text { Planting more number of trees and creation of green } \\
\text { spaces }\end{array}$ & 2.44 & 3.05 & 3.32 & 3.59 & 3.75 & 3.21 \\
\hline Sustainable long range environmental planning & 3.11 & 3.62 & 3.89 & 4.16 & 4.22 & 3.78 \\
\hline Preserving ecosystem and farmland & 2.38 & 2.99 & 3.26 & 3.53 & 3.69 & 3.15 \\
\hline Utilization of alternative energy sources & 4.04 & 4.20 & 4.22 & 4.25 & 4.29 & 4.20 \\
\hline Improving public transport & 1.86 & 2.47 & 2.74 & 3.01 & 3.17 & 2.63 \\
\hline Increasing energy efficiency & 1.62 & 2.23 & 2.50 & 2.77 & 2.93 & 2.39 \\
\hline $\begin{array}{l}\text { Utilization of large number of environmentally friendly } \\
\text { vehicles }\end{array}$ & 3.22 & 3.93 & 4.10 & 4.17 & 4.13 & 3.89 \\
\hline Accepting more plastics in recycling & 2.18 & 2.79 & 3.06 & 3.33 & 3.49 & 2.95 \\
\hline Proper placement of garbage binds & 3.06 & 3.57 & 3.84 & 4.11 & 4.17 & 3.73 \\
\hline Levying heavier fines on littering & 1.03 & 1.64 & 1.91 & 2.18 & 2.34 & 1.80 \\
\hline Need more publicity on hazardous waste profile & 1.93 & 2.54 & 2.81 & 3.08 & 3.24 & 2.70 \\
\hline Introducing green boxes in recycling & 3.48 & 3.79 & 4.06 & 4.23 & 4.29 & 3.95 \\
\hline Effective approach to recycling of waste & 1.68 & 2.29 & 2.56 & 2.83 & 2.99 & 2.45 \\
\hline Improving waste management & 2.57 & 3.18 & 3.45 & 3.72 & 3.88 & 3.34 \\
\hline Public information on location of waste dump sites & 1.57 & 2.18 & 2.45 & 2.72 & 2.88 & 2.34 \\
\hline Distribution of large number of recycling bins & 1.74 & 2.35 & 2.62 & 2.89 & 3.05 & 2.51 \\
\hline $\begin{array}{l}\text { Measures to make schools participate in recycling } \\
\text { programmes }\end{array}$ & 2.31 & 2.92 & 3.19 & 3.46 & 3.62 & 3.08 \\
\hline Developing large number of clean up programmes & 3.42 & 4.03 & 4.20 & 4.17 & 4.23 & 3.99 \\
\hline Establishing volunteer clean up programmes & 1.55 & 1.61 & 1.88 & 2.05 & 2.41 & 1.87 \\
\hline $\begin{array}{l}\text { Measures to make community involvement in clean up } \\
\text { programmes }\end{array}$ & 1.99 & 2.60 & 2.87 & 3.14 & 3.30 & 2.76 \\
\hline Need to improve the quality of air & 2.70 & 3.31 & 3.58 & 3.85 & 4.01 & 3.47 \\
\hline Measures to improve air quality management & 2.61 & 3.22 & 3.49 & 3.76 & 3.92 & 3.38 \\
\hline Starting new clean air initiatives & 2.12 & 2.73 & 3.00 & 3.27 & 3.43 & 2.89 \\
\hline Need programmes to deal specifically with pollution & 3.72 & 4.13 & 4.17 & 4.20 & 4.23 & 4.09 \\
\hline $\begin{array}{l}\text { Need more promotion and education of public in } \\
\text { sanitation }\end{array}$ & 1.57 & 1.78 & 2.05 & 2.12 & 2.28 & 1.94 \\
\hline $\begin{array}{l}\text { Creation of environmental awareness through mass } \\
\text { media }\end{array}$ & 1.51 & 2.12 & 2.39 & 2.66 & 2.82 & 2.28 \\
\hline
\end{tabular}

Table 2:-Education Wise Respondents' Rating on Environmental Conservation Measures (Cont..)

\begin{tabular}{|c|c|c|c|c|c|c|}
\hline $\begin{array}{l}\text { Need more information regarding environmental } \\
\text { policies and incentives }\end{array}$ & 2.76 & 3.37 & 3.64 & 3.91 & 4.07 & 3.53 \\
\hline $\begin{array}{l}\text { Identification of alternative energy sources for public } \\
\text { transport }\end{array}$ & 3.97 & 4.18 & 4.15 & 4.22 & 4.28 & 4.14 \\
\hline $\begin{array}{l}\text { Provide funding for research and use of wind, solar, } \\
\text { biomass and other renewable energies }\end{array}$ & 1.50 & 1.91 & 2.18 & 2.25 & 2.61 & 2.07 \\
\hline $\begin{array}{l}\text { Provision of more volunteer opportunities for young } \\
\text { people in environmental conservation }\end{array}$ & 2.81 & 3.42 & 3.69 & 3.96 & 4.12 & 3.58 \\
\hline $\begin{array}{l}\text { Public debate focusing on preventing environmental } \\
\text { issues }\end{array}$ & 1.59 & 2.00 & 2.17 & 2.44 & 2.70 & 2.16 \\
\hline Frequent conducting antilittering campaign & 2.05 & 2.66 & 2.93 & 3.20 & 3.36 & 2.82 \\
\hline Appoint of more sweepers to clean the streets & 2.87 & 3.48 & 3.75 & 4.02 & 4.18 & 3.64 \\
\hline Effective implementation of antilittering laws & 1.80 & 2.41 & 2.68 & 2.95 & 3.11 & 2.22 \\
\hline Average & 2.36 & 2.89 & 3.13 & 3.35 & 3.50 & 3.01 \\
\hline
\end{tabular}

Source: Computed from primary data 


\begin{tabular}{|l|r|r|r|r|c|}
\hline ANOVA Source of Variation & & & & & \\
\hline & \multicolumn{1}{|c|}{ SS } & \multicolumn{1}{c|}{$d f$} & \multicolumn{1}{c|}{ MS } & \multicolumn{1}{c|}{$F$} & $F$ crit \\
\hline Variation due to environmental conservation measures & 85.865 & 35 & 2.453286 & 146.948 & 1.507334 \\
\hline Variation due to Educational status & 28.87731 & 4 & 7.219328 & 432.4266 & 2.436317 \\
\hline Error & 2.337289 & 140 & 0.016695 & & \\
\hline Total & 117.0796 & 179 & & & \\
\hline
\end{tabular}

Data presented in table 2 indicate the education wise respondents' rating on measures of environmental conservation. The post graduate degree level educated respondents rank the first position in their overall rated measures on environmental conservation as per their secured a mean score of 3.50 on a 5 point rating scale. The under graduate degree level educated respondents record the second position in their overall rated in measures on environmental conservation as per their secured a mean score of 3.35 on a 5 point rating scale. The higher secondary educated respondents register the third position in their overall rated measures on environmental conservation as per their secured a mean score of 3.13 on a 5 point rating scale. The secondary level educated respondents hold the fourth position in their overall rated measures on environmental conservation as per their secured a mean score of 2.89 on a 5 point rating scale. The primary level educated respondents turn down to last position in their overall rated measures on environmental conservation as per their secured a mean score of 2.36 on a 5 point rating scale.

The anova two ways model is applied for further discussion. The computed anova value 146.94 is greater than its tabulated value at 5 percent level significance. Hence, the variation among the measures on environmental conservation is statistically identified as significant. In another point, the computed anova value 432.42 is greater than its tabulated value at 5 percent level significance. Hence, the variation among the educational groups is statistically identified as significant as per the respondents rated measures on environmental conservation.

Table 3:-Sex Wise Respondents' Rating on Environmental Conservation Measures

\begin{tabular}{|l|c|c|c|}
\hline \multicolumn{1}{|c|}{ Variables } & Male & Female & Mean \\
\hline Improving sewage system & 2.94 & 2.20 & 2.57 \\
\hline Effective enforcement of environmental regulations & 3.39 & 2.65 & 3.02 \\
\hline Planting more number of trees and creation of green spaces & 3.58 & 2.84 & 3.21 \\
\hline Sustainable long range environmental planning & 4.15 & 3.41 & 3.78 \\
\hline Preserving ecosystem and farmland & 3.52 & 2.78 & 3.15 \\
\hline Utilization of alternative energy sources & 4.27 & 4.13 & 4.20 \\
\hline Improving public transport & 3.00 & 2.26 & 2.63 \\
\hline Increasing energy efficiency & 2.76 & 2.02 & 2.39 \\
\hline Utilization of large number of environmentally friendly vehicles & 4.16 & 3.62 & 3.89 \\
\hline Accepting more plastics in recycling & 3.32 & 2.58 & 2.95 \\
\hline Proper placement of garbage binds & 4.10 & 3.36 & 3.73 \\
\hline Levying heavier fines on littering & 2.07 & 1.53 & 1.80 \\
\hline Need more publicity on hazardous waste profile & 3.07 & 2.33 & 2.70 \\
\hline Introducing green boxes in recycling & 4.22 & 3.68 & 3.95 \\
\hline Effective approach to recycling of waste & 2.82 & 2.08 & 2.45 \\
\hline Improving waste management & 3.71 & 2.97 & 3.34 \\
\hline Public information on location of waste dump sites & 2.71 & 1.97 & 2.34 \\
\hline Distribution of large number of recycling bins & 2.88 & 2.14 & 2.51 \\
\hline Measures to make schools participate in recycling programmes & 3.45 & 2.71 & 3.08 \\
\hline Developing large number of clean up programmes & 4.16 & 3.82 & 3.99 \\
\hline Establishing volunteer clean up programmes & 2.14 & 1.60 & 1.87 \\
\hline Measures to make community involvement in clean up programmes & 3.13 & 2.39 & 2.76 \\
\hline Need to improve the quality of air & 3.84 & 3.10 & 3.47 \\
\hline Measures to improve air quality management & 3.75 & 3.01 & 3.38 \\
\hline Starting new clean air initiatives & 3.26 & 2.52 & 2.89 \\
\hline Need programmes to deal specifically with pollution & 4.26 & 3.92 & 4.09 \\
\hline Need more promotion and education of public in sanitation & 2.31 & 1.57 & 1.94 \\
\hline Creation of environmental awareness through mass media & 2.65 & 1.91 & 2.28 \\
\hline
\end{tabular}




\begin{tabular}{|l|c|c|c|}
\hline Need more information regarding environmental policies and incentives & 3.90 & 3.16 & 3.53 \\
\hline Identification of alternative energy sources for public transport & 4.21 & 4.07 & 4.14 \\
\hline $\begin{array}{l}\text { Provide funding for research and use of wind, solar, biomass and other renewable } \\
\text { energies }\end{array}$ & 2.44 & 1.70 & 2.07 \\
\hline $\begin{array}{l}\text { Provision of more volunteer opportunities for young people in environmental } \\
\text { conservation }\end{array}$ & 3.95 & 3.21 & 3.58 \\
\hline Public debate focusing on preventing environmental issues & 2.53 & 1.79 & 2.16 \\
\hline Frequent conducting antilittering campaign & 3.19 & 2.45 & 2.82 \\
\hline Appoint of more sweepers to clean the streets & 4.01 & 3.27 & 3.64 \\
\hline Effective implementation of antilittering laws & 2.59 & 1.85 & 2.22 \\
\hline Average & 3.35 & 2.68 & 3.01 \\
\hline
\end{tabular}

Source: Computed from primary data

T statistical value 23.71 , df 35 , $\mathrm{t}$ critical value 1.68

Data presented in table 3 indicate the sex wise respondents' rating on measures on environmental conservation. The male respondents' rank the first positions in their overall rated measures on environmental conservation as per their secured a mean score of 3.35 on a 5 point rating scale. The female respondents' hold the second position in their overall rated measures on environmental conservation and it is estimated from their secured a mean score of 2.68 on a 5 point rating scale.

The $t$ test is applied for further discussion. The computed $t$ value 23.71 is greater than its tabulated value at 5 per cent level significance. Hence, there is a significant difference between male respondents' and female respondents' in their overall rated measures on environmental conservation.

\section{Conclusion:-}

It could be seen clearly from the above discussion that the respondents' rate the high level measures on environmental conservation by citing the facts that utilization of alternative energy sources, identification of alternative energy sources for public transport, need of programmes to deal specifically with pollution, developing large number of clean up programmes, introducing green boxes in recycling, utilization of large number of environmentally friendly vehicles, formulation of sustainable long range environmental planning, proper placement of garbage binds, appointment of more sweepers to clean the streets, provision of more volunteer opportunities for young people in environmental conservation and need of more information regarding environmental policies and incentives as per their secured a mean score above 3.50 on a 5 point rating scale. The respondents' report the moderate level environmental conservation measures by stating the facts that need to improve the quality of air, measures to improve air quality management, improving waste management, planting more number of trees and creation of green spaces, preserving ecosystem and farmland, measures to make schools participate in recycling programmes, effective enforcement of environmental regulations, accepting more plastics in recycling, starting new clean air initiatives, frequently conducting antilittering campaign, measures to make community involvement in clean up programmes, need for more publicity on hazardous waste profile, improving public transport, improving sewage system and distribution of large number of recycling bins as per their secured a mean score in the range of 2.50 to 3.50 on a 5 point rating scale. The respondents' rate the low level measures on environmental conservation by indicating the facts that effective approach to recycling of waste, increasing energy efficiency, public information on location of waste dump sites, creation of environmental awareness through mass media, effective implementation of antilittering laws, public debate focusing on preventing environmental issues, provide funding for research and use of wind, solar, biomass and other renewable energies, Need of more promotion and education of public in sanitation, establishing volunteer clean up programmes and levying heavier fines on littering as per their secured a mean score below 2.50 on a 5 point rating scale. It could be observed that the respondents belong to the above 20-25 years age group rank the first position in their overall rated measures on environmental conservation, respondents come under in the range of 25-30 years age group the second, respondents identified in the range of 30-35 years age group the third, respondents come under the in the range of 35-40 years age group the fourth, respondents come under in the range of 40-45 years age group the fifth and respondents observed in the range of 45-50 years age group the last.

The result of education wise analysis reveals that the post graduate degree level educated respondents rank the first position in their overall rated measures on environmental conservation, under graduate degree holder respondents 
the second, diploma level educated respondents the third, higher secondary level educated respondents the fourth and secondary level educated respondents the last. The result of gender wise analysis reveals that the female respondents lag behind the male respondents in their overall rated measures on environmental conservation.

\section{References:-}

1. Patricia Romero-Lankao, Hua Qin and Mercy Borbor-Cordova (2013), Exploration of health risks related to air pollution and temperature in three Latin American cities Social Science \& Medicine, vol. 83, issue C, pages 110-118

2. Duo Qin (2010), Long-term Nexus of Industrial Pollution and Income in China No 659, Working Papers from Queen Mary, University of London, School of Economics and Finance

3. Katja Coneus and Christa Katharina Spie (2010), Pollution exposure and infant health: Evidence from Germany

4. No 10-079, ZEW Discussion Papers from ZEW - Zentrum für Europäische Wirtschaftsforschung / Center for European Economic Research

5. Chunbo Ma (2010), Who bears the environmental burden in China--An analysis of the distribution of industrial pollution sources? Ecological Economics, vol. 69, issue 9, pages 1869-1876

6. Inge Mayeres and Denise Van Regemorter (2008), Modelling the Health Related Benefits of Environmental Policies and Their Feedback Effects: A CGE Analysis for the EU Countries with GEM-E3 The Energy Journal, vol. Volume 29, issue Number 1, pages 135-150

7. Xavier Pautrel (2007), Pollution, Health and Life Expectancy: How Environmental Policy Can Promote Growth No 2007.96, Working Papers from Fondazione Eni Enrico Mattei

8. Varaporn Punyawadee, Ratana Phothisuwan, Numpet Winichaikule and Kanitta Satienperakul (2007), Cost and Benefit of Flue Gas Desulfurization for Pollution Control at the Mae Moh Power Plant, Thailand No rr2007011, EEPSEA Research Report from Economy and Environment Program for Southeast Asia (EEPSEA)

9. Sunil Chandrasiri (2006), Health Impacts of Diesel Vehicle Emissions: The Case of Colombo No rr2006121, EEPSEA Research Report from Economy and Environment Program for Southeast Asia (EEPSEA)

10. Budy P. Resosudarmo and Lucentezza Napitupulu (2004), Health and Economic Impact of Air Pollution in Jakarta The Economic Record, vol. 80, issue s1, pages S65-S75

11. David Roland-Holst, G. Chris Rodrigo and Kenneth Reinert (2002), North American economic integration and industrial pollution in the Great Lakes region The Annals of Regional Science, vol. 36, issue 3, pages 483-495

12. Hua Wang and Yanhong H. Jin (2002), Ownership and Industrial Pollution Control: Evidence From China No 19671, Annual meeting, July 28-31, Long Beach, CA from American Agricultural Economics Association (New Name 2008: Agricultural and Applied Economics Association)

13. Hua Wang (2000), Pollution charges, community pressure, and abatement cost of industrial pollution in China No 2337, Policy Research Working Paper Series from The World Bank

14. Hercules Haralambides and Girish Gujar (2012), "On balancing supply chain efficiency and environmental impacts: An eco-DEA model applied to the dry port sector of India" Maritime Economics and Logistics, vol. 14 , issue 1 , pages $122-137$

15. Rema Hanna and Michael Greenstone (2011), "Environmental Regulations, Air and Water Pollution, and Infant Mortality in India" Working Papers from social Sciences

16. Amit Garg (2011), "Pro-equity Effects of Ancillary Benefits of Climate Change Policies: A Case Study of Human Health Impacts of Outdoor Air Pollution in New Delhi” World Development, vol. 39, issue 6, pages 1002-1025

17. Michael Greenstone and Rema Hanna (2011) "Environmental Regulations, Air and Water Pollution, and Infant Mortality in India" Working Paper Series from Harvard University, John F. Kennedy School of Government

18. M.N. Murty (2010), Working Papers "Designing Economic Instruments and Participatory Institutions for Environmental Management in India" from eSocialSciences

19. Ramakrishna B. M and Jayasheela (2010), "Environmental Problems and Sustainable Development: With Special Reference to India Issues and Challenges" Journal of Global Economy, vol. 6, issue 2, pages 95-104

20. Kakali Mukhopadhyay (2008), "Air pollution and income distribution in India" Asia-Pacific Development Journal, vol. 15, issue 1, pages 35-64

21. Prakash Nelliyat (2007), Industrial Growth and Environmental Degradation: A Case Study of Tiruppur Textile Cluster Prakash Nelliyat: MSE Development Economics Working Papers from East Asian Bureau of Economic Research

22. M. Narsimha Murty, Surender Kumar and Kishore Kumar Dhavala (2007) Measuring environmental efficiency of industry: a case study of thermal power generation in India Environmental \& Resource Economics, vol. 38, issue 1 , pages $31-50$ 
23. Sacchidananda Mukherjee and Prakash Nelliyat (2006) "Ground Water Pollution and Emerging Environmental Challenges of Industrial Effluent Irrigation: A Case Study of Mettupalayam Taluk, Tamilnadu” Development Economics Working Papers from East Asian Bureau of Economic Research

24. Ramprasad Sengupta and Subrata Mandal (2005), Health damage cost of automotive air pollution: Cost benefit analysis of fuel quality upgradation for Indian cities Ramprasad Sengupta: Jawaharlal Nehru University

25. Subrata Mandal: National Institute of Public Finance and Policy Working Papers from National Institute of Public Finance and Policy

26. Shaman, David (1996), "India's Pollution Regulatory Structure and Back Ground" NIPR, the World Bank Group, http://wb.forumone.comlniprcd/indialindiaback. htm.

27. Kuik, 0., et.al (1997), "Pollution control in the South and North- A Comparative Assesment of Environmental Policy Approaches in India and the Netherlands." Sage Publications, new Delhi.

28. Sankar, Ulakanathan (1998), "Laws and Institutions Relating to Environmental protection in India" Paper presented at the Conference on the Role of Law and Legal Institutions in Asian Economic Development, Rotterdam.

29. Murty, M.N (2000), "Environmental Regulations and Economics of Developmental Policies" Working Paper, Institute of Economic Growth, New Delhi.

30. Parikh, S. Kirit., Jyoti K. Parikh., T. R. Muraleedharan and Nandini Hadkar (1994), "Economic Valuation of Air pollution in Chembu(, Bombay, India" IGIDR, Mumbai.

31. Abu backer, (1994), "Controlling Industrial Pollution," World Bank Policy Research Working Paper: 1672, World Bank, Washington D.e.

32. Cropper M., Simon., Alberini., Arora Seema and Sharma P.K (1997), "The Health Benefits of Air Pollution Control in Delhi". American Journal / Agricultural Economics, (79), No:5, pp: 1625-1629

33. Pigou, A.C (1920), "The Economics of Welfare" Mac Million, London Dorfman, Robert., and, S. Dorfman. (1972), "Economics of the Environment - Selected Readings" W.W. Norton and Company.Inc. New York.

34. Murthy M.N. and Surender Kumar (2002), Chapter 5, Environmental and Economic Accounting for industry, Oxford University Press, New Delhi.

35. US Department of Health, Education and Welfare, National Center for Health Statistics. 'Health procedure, Vital and Health Statistics programs and Collection Procedures" (1964), Series No.1, No:2

36. Freeman III Myrick, M. (1993), "The Measurement of Environmental and Resource Values; Theory and Methods". Page: 315, Resources for the Future, Washington D.C 